\title{
Application of Green Construction in the Fortune Center Project of CCCC
}

\author{
Xiaozhi Zhang \\ Beijing United Development Co., Ltd of CCCC, China \\ xiaozhich@163.com
}

Keywords: green construction, construction technology, project management

Abstract. In the engineering construction of real estate projects, green construction is that under the premise of the basic requirements such as guarantee quality, safety, etc., saving resources and reducing the negative impact to the environment to the maximum limit through scientific management and technological progress. For China is still in its initial stage of urbanization, real estate industry with a large amount of consumption of resources and environmental impact, should be full implementation of green construction, undertake the social responsibility for sustainable development. Combining with the fortune center project of China Communications Construction Company (CCCC) in Shijiazhuang city of Hebei province, this article analyzes the practical application of green construction in the course of specific projects construction in brief.

\section{Introduction}

The development of green construction is the development direction of the current and future real estate industry [1].The fortune center project is opposite the Zhongshan stadium at the Ziqiang Street in Qiaoxi District of Shijiazhuang city in Hebei province. The aerial view of the project is as shown in Fig.1. The construction site is the original 135 plots of the second rest house in Hebei province, which is located in the city's core region. It is close to the residential area on the east side, Hebei China hotel on the north side, Hebei provincial government on the west side, and the second rest house in Hebei province on the south side. The surrounding environment is complex and construction site is narrow.

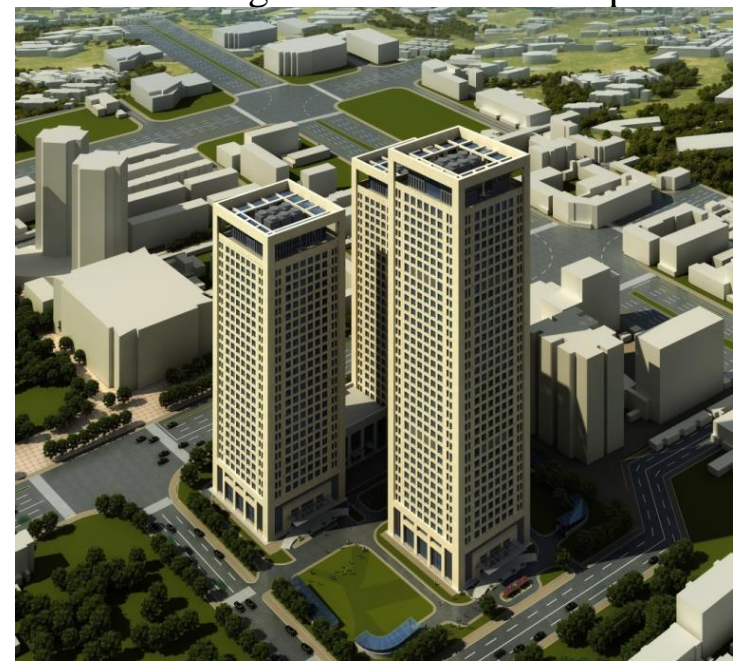

Fig.1 Aerial view of the project

The project area is 22400 square meters. Its total construction area is $183046.79 \mathrm{~m}^{2}$, including the ground construction area $125126.18 \mathrm{~m}^{2}$ and underground construction area $57920.61 \mathrm{~m}^{2}$. Volume rate is 5.82 , building density is $26.39 \%$, and green rate is $25 \%$.

The building consists of T1, T2, T3 three main buildings and subsidiary skirt building. T1, T2 have 24 floors on the ground, the building height is 99.9 meters. T3 has 28 floors on the ground, and the building height is 124 meters. The skirt building has 3 floors on the ground, building height is 16.8 meters, and underground part of this building has 4 floors.

The project is positioned as a high-end office projects, and it belongs to super high and overrun buildings in the construction. 


\section{Green Construction Goal}

According to the provisions of the relevant document, such as the architectural form of the building itself, the green building demonstration project in Hebei province, the national green construction demonstration project construction and the "national green building three star", the total target of project green construction is to create a demonstration project of Hebei construction science and technology and a "national demonstration project of green construction in building industry"[2,3]. In addition, as a green construction standard template among the projects developed by Beijing United Development Co., Ltd of CCCC, this project will be referred by the late real estate projects.

Combining with the engineering regional location, project positioning, the surrounding environment, the evaluation standard for green construction, the target for green construction is decomposed in detail as follows[4,5].

(1) Environmental protection, see table 1.

Table 1 Decomposition form of green construction index

\begin{tabular}{|l|l|l|}
\hline $\begin{array}{l}\text { Serial } \\
\text { number }\end{array}$ & $\begin{array}{l}\text { Environmental } \\
\text { objectives }\end{array}$ & Environmental objectives specification \\
\hline 1 & noise & $\begin{array}{l}\text { Noise emission conforms to the requirement of the construction } \\
\text { field noise limit }\end{array}$ \\
\hline 2 & dust & $\begin{array}{l}\text { Dust and gases emission is not more than the limited value of laws } \\
\text { and regulations }\end{array}$ \\
\hline 4 & solid & $\begin{array}{l}\text { Reduce the production of solid waste, and recycle construction } \\
\text { waste reasonably }\end{array}$ \\
\hline 5 & sewage & $\begin{array}{l}\text { Production and living sewage emission conforms to the requirement } \\
\text { of the integrated wastewater discharge standard }\end{array}$ \\
\hline 6 & $\begin{array}{l}\text { Reduce the consumption of water and electricity, paper, materials } \\
\text { and other resource, classify the construction garbage, and recycle as } \\
\text { much as possible }\end{array}$ \\
\hline four $100 \%$ & $\begin{array}{l}\text { Construction site is enclosed 100\%; Site sandy soil coverage } \\
\text { reaches 100\%; Site road is hardened 100\%; Spraying water to } \\
\text { reduce the dust for demolition engineering reaches 100\% }\end{array}$ \\
\hline
\end{tabular}

(2) Land saving and construction land protection: effective utilization rate of temporary facilities area is greater than $90 \%$

(3) Energy saving and energy utilization: power consumption index of ten thousand yuan output value is within $100 \mathrm{KWH}$.

(4) Water saving and water resource utilization: water consumption index of ten thousand yuan output value is within $10 \mathrm{t}$.

(5) Material saving and material resource utilization: main material attrition rate is $30 \%$ lower than the norm attrition rate; Local materials, the building materials consumption accounts of construction site within $500 \mathrm{~km}$ production is more than $70 \%$ of the total amount of building materials; repeatable utilization rate of temporary materials reached $70 \%$.

\section{Organization Management}

3.1 Management System. The green construction of the fortune center project of CCCC involves the whole project construction process and the subsequent use process, closely relates to each cooperated-building units. To face to the engineering status that the construction site scope is narrow, and the surrounding environment is extremely complicated, and to strengthen the organization and coordination of the green construction of this project, the integrated green construction leading group is established, including the developers (project manage company), the supervision unit, the general contracting unit, the subcontracting unit, which replaces the management system led by the three 
green construction leading group including the developers, supervision unit, and general contractor unit in the past. For the general contracting unit is the main body of green construction, the project manager of the general contracting unit is appointed as team leader, the site manager of the developers and the chief engineer of the supervision unit are appointed as supervision leaders, who will supervise the whole engineering.

3.1.1 Application Range. Green construction application framework is composed of six aspects, including construction management, environmental protection, material saving and material resources utilization, water saving and water resource utilization, energy saving and energy use, land saving and construction land protection. These aspects covers the basic indexes of green construction, in the meantime, they contains the subsets of every stage indexes, which include the construction planning, material procurement, site construction, project acceptance and so on.

3.1.2 Management Measures. The Executive team leader organizes team members to attend the green construction coordination meeting regularly. The existing problems, which include construction management, environmental protection, material saving and material resources utilization, water saving and water resource utilization, energy saving and energy use, land saving and construction land protection, are classified and coordinated to solve. For site daily green construction problems, through the sign to recognize, leading group members confirm corrective actions and responsibility unit.

\section{Site Management}

In the site management, managers mainly do the following aspects, and the corresponding technical measures, such as green construction propaganda, environmental protection, dust suppression, waste control, noise control, control of light pollution, control of the discharge of sewage, waste gas control, personnel health, material saving, water saving, energy saving and land conservation.

\section{Construction Technology}

5.1 New Process and New Technology. The nature of the project is positioned as a high-grade office building and intelligent office. It also belongs to one of the landmark buildings in Shijiazhuang city. For the engineering height has exceeded standard, many new processes and new technologies have be adopted in the process of engineering construction.

5.1.1 Green Construction Technology. Green construction technology is listed as follows.

(1) Ready-mixed mortar technology

The ready-mixed mortar is produced by professional factory, which is used in all kinds of mortar mixture in this project. Compared with the traditional site mixing mortar, the ready-mixed mortar promotes construction technology progress. It not only can improve the quality of the construction project and the level of construction civilization, but also can reduce the air pollution and noise pollution, save resources and protect the environment.

(2) Attached lifting scaffold technology

The attached lifting scaffold of three towers is just set up the 4 or 5 layers in this project, which just climbs step by step with the main structure construction. Depending on the bearing capacity of the concrete poured on the building, the attached lifting scaffold and lifting mechanism are fixed respectively on the building structure. When it is lifting, the constraints linking to scaffolding and buildings are untied and ones linking to scaffolding and lifting mechanism should be applied. Lifting in place, the scaffolding will be fixed on the building, and the constraints linking to scaffolding and lifting mechanism are untied, so step by step. With attached lifting scaffold technology, the hazards of a large number of ordinary high frames set-up operation can be reduced to a great extent. At the same time it can save a lot of steel pipes, fasteners and other turnover materials.

(3) Wall self-insulation system

The materials of partition wall between heating air conditioning room and non-heating air conditioning room are autoclaved aerated concrete blocks with $200 \mathrm{~mm}$ thick in this project. The 
blocks of upper and lower layers should be staggered. The undersurface of the floor connecting with the wall is provided with $20 \mathrm{~mm}$ thick inorganic fiber insulation material, so as to ensure that the heat preservation and energy saving effect of the non-heating air conditioning room is in accordance with the specification requirements.

(4) Paste type thermal insulation system outside the external wall

The insulation board is $60 \mathrm{~mm}$ thick rock wool composite plate, which can greatly reduce energy consumption of the building heating and cooling, save the economic costs.

This project uses the autoclaved aerated concrete blocks with $200 \mathrm{~mm}$ thick as the external wall. $60 \mathrm{~mm}$ thick rock wool composite plate is affixed to the exterior surface of the external wall by adhesive, and the anchoring point is set in the four corners and the middle of horizontal seam of the plate with special rock wool anchor. Polymer mortar is wiped on the surface of rock wool plate and reinforced mesh is paved, and then the finishing layer is done, the basic structure is shown in Fig. 2.

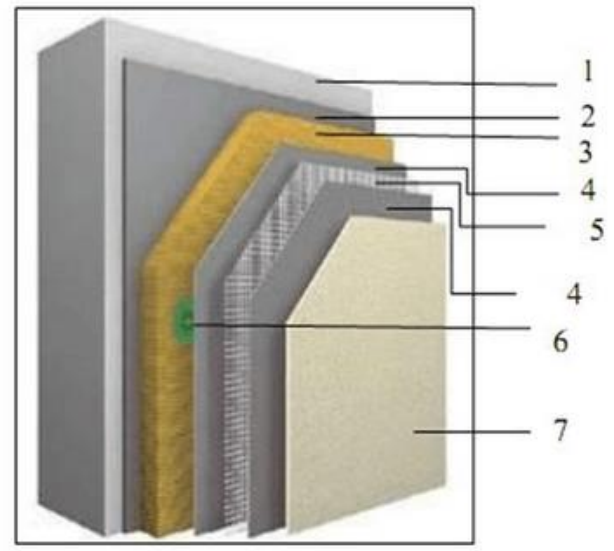

1-Base wall

2- Adhesive

3- Rock wool composite plate

4- Polymer mortar

5- Reinforced mesh

6- Anchor

7- Finishing layer

Fig.2 Insulation structure of the external wall

\section{Conclusions}

To develop the research on policy and technology of green construction, to earnestly implement the green concept in the planning and design stage of real estate projects, to promote new technologies, new equipment and new materials in the construction stage, has been the main stream of the industry development, which is the unification of economic benefits, social benefits and environmental benefits within the whole life cycle of real estate project.

The fortune center project of CCCC is honored with the second batch of provincial civilized construction site of Hebei province in 2015. At the same time, it is also honored with 'AAA Safe and civilized standardization construction site' by the construction safety branch of China's construction industry association.

\section{References}

[1] Xuwen Xiao, Dakuo Feng: Construction Technology, Vol. 42 (1), p.12-15 (In Chinese).

[2] Green Construction Guideline (build quality (2007) No. 223), Ministry of Housing and Urban-Rural Development of the People's Republic of China (2007).

[3] China Construction First Building (Group) Co., Ltd.: Management Regulations for Green Construction (DB11/513-2008), Beijing Municipal Construction Committee (2008).

[4] China Academy of Building Research: Evaluation Standard for Green building (GB/T50378-2006), China Building Industry Press (2006).

[5] China State Construction Engineering Co., Ltd. : Evaluation Standard for Green Construction of Buildings Green (GB/T50640-2010), Ministry of Housing and Urban-Rural Development of the People's Republic of China (2011). 